\title{
Intercultural (Im)politeness
}

\author{
Chapter · May 2017
}

DOI: 10.1057/978-1-137-37508-7_23

CITATIONS

0

\section{2 authors:}

\section{Michael Haugh}

The University of Queensland

109 PUBLICATIONS 1,497 CITATIONS

SEE PROFILE
READS

416

Some of the authors of this publication are also working on these related projects:

Politeness, Impoliteness, and Ritual: Maintaining the Moral Order in Interpersonal Interaction.

Project Cambridge: Cambridge University Press (in press). View project

Project $\quad$ corpus linguistics View project 


\title{
Intercultural (im)politeness
}

\author{
Michael Haugh and Dániel Z. Kádár
}

\section{Introduction}

This chapter explores the relatively understudied area of intercultural (im)politeness. The fact that intercultural (im)politeness has not been a primary focus of (im)politeness researchers may be surprising in light of the fact that culture itself has played an extremely important role in the field since its foundations, albeit one that has been increasingly contested. However, the bulk of such explorations of (im)politeness have been cross-cultural rather than intercultural by nature. That is, the vast majority of studies have analysed (im)politeness in intracultural settings, and compared such cases across cultural groups, rather than in encounters between interactants with different cultural backgrounds.

There are a number of possible explanations as to why (im)politeness in intercultural settings has been relatively neglected by researchers. One reason is the assumption that communication with others of more or less the same cultural background is the unmarked norm, and that intercultural encounters are somehow less ubiquitous. It is for that reason, perhaps, that a specific theory of intercultural (im)politeness has yet to be developed (Haugh, 2010; Kecskes, 2013), in spite of the fact that theories of intercultural communication abound. However, such an assumption seems out of step with the lived reality of migrants, increasing recognition of the fundamentally multicultural nature of societies, the possibilities afforded by a world wide web, and the ever increasing forces of globalisation.

A second, somewhat related reason is that what counts as an intercultural encounter has become increasingly difficult to say. Sifianou (2013), for instance, has argued that politeness behaviour in institutional encounters is increasingly following 'international' norms due to the pressures of globalisation. In such cases, the encounters in question may not display any interculturally salient phenomenon, at least not of the sort studied by (im)politeness researchers to date. Consequently, if one places such interactions under the lens of putative cultural differences one risks forcing one’s own analytic agenda onto the data studied (Kádár \& Haugh, 2013).

Third, a highly reductive notion of culture that is associated primarily with nation states has left (im)politeness researchers with an analytical tool that does not do justice to the inevitable complexity of social interaction. The traditional notion of culture its seemingly natural relationship with nation states, has come under considerable fire in the past few decades. It is broadly accepted in the humanities that culture has many layers (see Clifford's [1988] seminal study). Indeed, people frequently engage in intercultural interaction in their daily lives, often without noticing it: in a sense, asking an administrative colleague to help with an academic matter in a university may be construed as an 'intercultural' request, as different identifiable communities of practice within workplaces tend to have different interactional cultures (however small such differences might seem). Yet if we take such a stance to its natural conclusion, for instance, in the guise of Holliday's (1999) arguments regarding "small cultures", it leads us to fracturing our analyses to the point that almost any interaction can be regarded, at least in some respects, as intercultural. This might seem, at 
first glance at least, to provide a theoretical way out of using 'culture' as a generalising concept, as it over-turns the traditional assumption that what underpins communication is common ground and that intercultural encounters inevitably give rise to misunderstandings and troubles (Sarangi, 1994). However, it ignores the very real ideological power of culture at all levels of groups from small communal groups or communities of practice through to large and diffuse national groupings as a resource for participants (Carbaugh, 2012), as well as the manner in which the practices, beliefs, values and so on can vary in systematic ways across persons that simply cannot all be accounted for at the level of 'small cultures' or 'communities of practice' (Mills, 2011).

A fourth, related reason, is that there still remains considerable theoretical debate amongst scholars about the relationship between culture and the behaviour of members of that culture (Spencer-Oatey and Franklin, 2009). In other words, what is the link between the values and beliefs espoused by members of a culture, and the practices through which they constitute their daily lives? In many approaches to date it has been assumed that cultural values translate into cultural norms or schema of behaviour (e.g. Hofstede, 1991). However, such an assumption is problematic as abstract cultural values evidently do not readily translate into observable behaviours (McSweeney, 2002), and it also ignores the inevitable variability in the actual behaviours of members (Eelen, 2001). In our view, an approach to culture, such as that espoused by Hofstede (1991), confounds two potentially distinct objects of analysis. On the one hand, there are regularities in how members do and mean things in interaction, that is, the ways in which we accomplish and make sense of the social actions, meanings, activities and so on that constitute our daily interactions. On the other hand, there are regularities in the ways in which members evaluate those social actions, activities, meanings and so on. We need to be studying such regularities at multiple levels, and examining the extent to which they correlate with the values, beliefs and so on that are both explicitly and implicitly conceptualised by members.

Thus, while overly simplistic generalisations about (im)politeness amongst the Japanese or British speakers of English might be difficult to defend in the face of the fact that there is invariably some degree of variation in how "(im)politeness" is conceptualised and practised amongst members of these respective speech communities, it would be equally naïve to assume that it doesn't matter for the analysis of (im)politeness what language(s) a person speaks or where they have grown up. (Im)politeness in intercultural encounters is a very real and potentially omnipresent concern for those participants. What is required, then, is not a full-scale abandonment of intercultural (im)politeness as a locus of research, but rather engagement with the inevitable complexity of analysing and theorising (im)politeness in such settings. In this chapter, we attempt to do just that.

We begin, in section two, by discussing some of the key concepts that are relevant to intercultural (im)politeness research, before offering, in section three, an overview of some the key findings in research to date. We then present, in section four, two small case studies that highlight key issues in the study of intercultural (im)politeness, before concluding with a brief summary and reflections on possible future directions in the field. 


\section{Key concepts}

The study of intercultural (im)politeness lies at the intersection of two complex, fundamentally interdisciplinary fields, namely, sociopragmatics and intercultural communication. Given that sociopragmatics is discussed at length in a number of chapters in this volume (see, e.g., Culpeper and Terkourafi, this volume; Mills, this volume), we will focus our discussion on the latter. Intercultural communication as a field involves multiple disciplinary strands and a diverse range of theories and approaches, as frequently noted in various handbooks of intercultural communication (e.g. Jackson, 2012; Paulston, Kiesling \& Rangel, 2012). Thus, rather than attempting to summarise all of these approaches and theories ${ }^{1}$, our discussion here is focused on key concepts in the field of intercultural communication that we consider to be of particular relevance to the study of (im)politeness in intercultural encounters, namely: (1) culture and communication, (2) perspectives, footings and the emic-etic distinction, (3) identities and identification, and (4) adaptation and interculturality.

\subsection{Culture and communication}

Intercultural communication as a field lies at the intersection of two concepts that have attracted considerable debate in a wide range of other fields across the humanities and social sciences, namely, 'culture' and 'communication'. The primary site of research is communicative interactions across or between participants who are identified by researchers, and/or identify themselves, as belonging to different cultural groups. The question of what constitutes a cultural group in the context of such encounters was traditionally linked to the nationality and first language of those participants. However, in recent decades a more finelygrained notion of cultural group has emerged. Culture is commonly used to refer to any set of persons who can be classed or categorised as having some kind of association through shared beliefs, values and practices, that is, shared ways of doing things as well as shared ways of interpreting or thinking about things in the world (Scollon and Scollon, 1995; Spencer-Oatey, 2000). Culture is thus both multi-layered, involving various social groupings ranging from family or other communal living groups to communities of practices through to diffuse relational networks, and multi-faceted, involving recurrent ways of doing, perceiving and evaluating and so on at all levels of social life. It is through the way in which members are held morally responsible with respect to these recurrent ways of doing, perceiving, evaluating and so on that such social groupings are infused with an ideological ethos.

On this view of culture, nationality and first language (L1) are just some of the grounds for categorising groups of persons, albeit ones that are invested with considerable ideological power. Of course, persons can be divided into various types of social groupings by both lay and professional analysts. However, it is only in cases where members of a particular social grouping are held normatively accountable to recurrent ways of doing, perceiving, evaluating and so on, thereby infusing this social grouping with an ideological ethos, that it can be analysed as a 'culture', and not merely a social group, both by members themselves and the professional analyst.

\footnotetext{
${ }^{1}$ See Martin, Nakayama \& Carbaugh (2012) for a judiciously balanced and very useful overview of the field.
} 
From the perspective of (im)politeness research what is critical about the notion of culture is that it offers the moral grounds for making such evaluations in the first place (Culpeper, 2011; Kádár \& Haugh, 2013). In other words, without recourse to recurrent, "seen but unnoticed” ways of going about our everyday lives (Garfinkel, 1967), there are no grounds upon which participants may evaluate the talk and conduct of others (and ourselves) as "good”, “bad”, “appropriate”, “inappropriate”, “polite”, “impolite” and so on (Haugh, 2013a). The complication in the case of intercultural encounters is that the moral grounds for such evaluations cannot be readily presumed by participants, but must inevitably be negotiated across multiple perspectives. To negotiate such understandings does not mean, however, that participants invariably reach the same understandings. Wolf (2015), for instance, argues that

the realisation of some anomaly, i.e., of some cultural difference will start the hermeneutic circle of interpretation and reinterpretation, until the partners engaged in an intercultural dialogue will, asymptotically ${ }^{2}$, achieve a degree of mutual understanding, or to use Gadamer's term, a ‘fusion of horizons' (Gadamer, 1989: 306) [...] This process cannot be achieved in singular encounters, but requires continuous intercultural exposure. (p.448)

In other words, negotiating understandings in intercultural encounters benefits from ongoing exposure to cultural others along with some degree of "mindfulness" on the part of those participants (Žegarac, Spencer-Oatey \& Ushioda, 2014). This explains seemingly contradictory findings that while in some cases diverging understandings and practices can lead to interactional discomfort or offence (e.g. Chang \& Haugh, 2011; Clyne 1994; Holmes, Marra \& Schnurr, 2008; Lee-Wong, 2002; Nakane, 2006), in other cases participants may attempt to accommodate themselves to the cultural other, thereby accomplishing positive impressions of the other and smoothing over any potential offence (Bubel, 2006; House, 2008, 2010; Kecskes, 2013; Kidwell, 2000; Miller, 1995; Ryoo, 2005).

Such studies also invariably build on various theoretical approaches to the question of what constitutes culture. In the field of intercultural communication these approaches can be broadly grouped into three inter-related streams: cognitive, interactional and critical. The first stream sees culture as a form of knowledge, and takes what is sometimes termed the "functionalist" approach to analysing intercultural encounters (Martin, Nakayama \& Carbaugh, 2012). Researchers aim to systematically describe cultural knowledge and how it underpins the degree to which intercultural encounters are perceived to be "successful" or "unsuccessful” (Busch, 2009). Early work along these lines tended to use methods and approaches from social psychology, in which "politeness systems" and "face" are conceptualised and operationalised as possible impediments to successful communication (e.g. Imahori \& Cupach, 2005; Ting-Toomey \& Kurogi, 1998). More recent work in

\footnotetext{
${ }^{2}$ Asymptotically means, more or less, to approach a value or line but never quite reach it. In other words, in intercultural interaction we might approach very closely to some kind of mutual understanding, but such understandings are unlikely to ever be fully aligned between participants. This phenomenon may not be limited, of course, to so-called intercultural interactions.
} 
pragmatics, particularly that undertaken under the banner of rapport management theory (e.g. Spencer-Oatey, 2000; Spencer-Oatey \& Xing, 2003) or intercultural pragmatics (Kecskes, 2013), has regarded such knowledge as much more dynamic and individuated. The notion of “distributed cognition” in cultural linguistics (Sharifian, 2011) arguably offers a potentially useful theoretical basis for developing a much more dynamic, cognitively-oriented account of (im)politeness in intercultural encounters.

The second stream treats culture as involving practices, that is, recurrent or preferred ways of doing, thinking and categorising people, and takes what is sometimes termed an “interpretive” approach to analysing intercultural encounters (Scollon, Scollon \& Jones, 2012). Much of this work has come under the banner of interactional sociolinguistics (Gumperz, 1982), although the focus has shifted away from culture as a "macro-level" category, where it is assumed that membership in a defined cultural group can be readily attributed to participants in intercultural encounters, to one in which the focus is on the ways in which participant signal cultural membership in such encounters. The notion of "community of practice" (CofP) has taken a central place in accounts of (im)politeness in intercultural encounters (Holmes, Marra \& Schnurr, 2008; Holmes, Marra and Vine, 2012), although as Marra (2015: 381) points out there are only a few studies that have actually tracked the development of the practices and putative normative constraints immanent to communities of practice in analysing (im)politeness. In any case, given intercultural encounters often arise outside of what could legitimately be deemed a community of practice, there remains further theoretical work to be done to anchor the practices that are assumed to underpin evaluations of (im)politeness within a broader account of culture that goes beyond communities of practice (Mills, 2011).

The third stream treats culture as an inherently ideological resource for perpetuating power imbalances or inequalities, and takes what is sometimes termed a "critical" approach to analysing intercultural encounters (Halualani, Mendoza \& Drzewiecka, 2009, Holliday, 1999; Martin \& Nakayama, 1999). The primary focus in such approaches is on analysing intercultural encounters as "site[s] of struggle where various communication meanings are contested within social hierarchies” (Martin, Nakayama \& Carbaugh, 2012: 28). While ideology and power has become an important focus of analysis in broadly discursive accounts of (im)politeness (Eelen, 2001; Mills, 2003; Watts, 2003), there has been limited application of such ideas to the analysis of (im)politeness in intercultural encounters to date. Instead, they have been taken up in approaches that explicitly combine interpretive and critical approaches, such as cultural discourse analysis (CuDA) (Carbaugh, 2005, 2012), or discursive pragmatics (e.g. Grainger and Mills, 2015).

The notion of culture is foundational to the analysis of (im)politeness in intercultural encounters, yet it is a concept that has been the subject of considerable debate. However, whether one elects to treat culture as a form of distributed knowledge, recurrent practices, or hegemonic ideology, one issue that has largely been neglected in such accounts is an account of the mechanisms by which such knowledge, practices or ideologies are developed and shared. The theoretical distinction between "prior context" (rooted in the prior experiences of individuals) and "actual situational context” (Kecskes, 2013) offers one way forward in better 
understanding such mechanisms at the level of individual intercultural encounters, although it remains to be tested through systematic analysis of (im)politeness in intercultural encounters.

\subsection{Warranting analyses of encounters as intercultural}

It has sometimes been assumed by researchers in intercultural communication that because participants are from different national or ethnic backgrounds that what ensues is an intercultural interaction. van der Bom and Mills (2015), for instance, have recently argued that cultural norms in intercultural interactions are "discursively negotiated" (p. 191). Their argument is based on their finding that in an interaction where three participants in the interaction identify themselves as Dutch and another as Italian, evaluations of (im)politeness are evidently negotiated by them rather than being dictated by their different cultural backgrounds. While it is made abundantly clear that these evaluations of (im)politeness are indeed discursively accomplished, it is not so clear what makes those sequences in question intercultural as opposed to simply interpersonal. Indeed, nowhere in their analysis is the notion of culture (or cultural resources, practices and so on) actually discussed. Yet without doing so, the analyst runs the risk of treating an encounter as intercultural one when there is little evidence to support the assumption that culture is in fact being manifested in that particular interaction. It is thus important, in our view, for the analyst to provide a warrant for their analysis of the interaction in question as one which is intercultural, as opposed to constituting an interpersonal one, that is, between two or more persons. The study of intercultural (im)politeness involves analysing how different cultural resources and practices are invoked or brought to bear by participants in the accomplishment of evaluations of (im)politeness. To examine intercultural (im)politeness, then, requires an additional layer of analysis where the researcher offers a clear warrant for his or her assumption that we are in fact dealing with an intercultural encounter.

One approach to warranting our analyses of (im)politeness as intercultural in nature is to draw from the orientations of the participants themselves to issues of culture or cultural group membership in the course of that interaction itself (Miller, 1995), or in subsequent interactions. In the latter case, these may be naturally occurring or elicited by the researcher through post-facto interviews (Günthner 2000; House, 2008; Spencer-Oatey and Xing, 2003). A second approach is to attempt to triangulate the findings from interactional analyses with findings from ethnographic work, including such methods as participant observation, interviews or questionnaires, document analysis and so on, carried out at the site where the data was collected (Bailey, 1997; Lee-Wong, 2002; Miller, 1995). A third approach is to elicit evaluations of interactions from lay observers who identify themselves with different cultural groups on the encounter in question (Chang and Haugh, 2011). While there are likely to be yet other approaches, what is critical for (im)politeness researchers is not simply to assume that because participants evidently identify with different cultural groups that the interaction that ensues is, by definition, intercultural.

Yet no matter which approach is taken to warranting one's analysis of an encounter as one that is (potentially) intercultural, it is important for the researcher to always bear in mind the observer's paradox (Labox, 1972). While this is generally understood to refer to the way in which the systematic collection of data by researcher's can influence the actions or 
behaviours of those being observed, there is another additional layer that needs to be borne in mind in the case of studying intercultural (im)politeness, namely, the way in which the cultural background of the observing researcher can influence his or her interpretations of what is being accomplished by those participants. Ramírez-Cruz (forthcoming), for instance, found that in course of ongoing ethnographic observations of a taco stand in Pittsburgh, USA, the Hispanic researcher perceived significantly more friendly stances on the part of customers (both Hispanic and White Americans) than the Anglo-American researcher (31.4\% as opposed to $12.7 \%$ ). What we are dealing with here, then, is the potential for observer bias, something which is particularly acute in the case of studies of (im)politeness, in which the object of study is inherently subjective, that is, rooted in the perspectives of persons rather than being objectively verifiable independent of those persons.

\subsection{Perspectives, footings and the emic/etic distinction}

The emic/etic distinction revolves around issues of claimed, assumed or perceived membership in cultural groups, and the different perspectives on talk and conduct vis-à-vis (im)politeness that can arise therein. An emic perspective represents how cultural insiders or members understand things, while an etic perspective stands for the understandings of a cultural outsider (Pike, 1967). In linguistic anthropology, an etic perspective is typically taken to be that of the researcher (Harris, 1976), but in intercultural encounters it also represents the perspective of the cultural "other". ${ }^{3}$ Thus, while these notions have been popularised in (im)politeness research more broadly in Eelen’s (2001) seminal work, they arguably have particular importance when researching (im)politeness in intercultural encounters at both the interactional and metapragmatic levels of analysis (Kádár \& Haugh, 2013).

In the course of an intercultural encounter, while one's evaluations of one's own talk is grounded in an emic perspective (whether one is talking about Mead's [1934] individuated perspective on self, the "I", or the perspective of the "generalised other" on self, the "me"), one's evaluations of the others' talk or conduct is grounded in an etic perspective from the perspective of that other participant, and vice-versa. To illustrate what we mean by that, let us consider the following intercultural apology discussed by Chang and Haugh (2011). ${ }^{4}$

(1) (Joyce has called Wayne after he did not turn up to a pre-arranged dinner) ${ }^{5}$

$13 \mathrm{~W}$ : it's just, a:h, I really apologise for not getting back

14 to you the other day but we couldn't make it?

[move 1: apology]

\footnotetext{
${ }^{3}$ While the term 'emic' is consistently used in the literature to refer to an "insider/member's" perspective, there is some variation in how the term 'etic' is deployed. In many studies it is considered to be synonymous with a "scientific" perspective given in anthropology an outsider's perspective was traditionally synonymous with that of the researcher. We use the term 'etic' in Pike's broader sense, however, to refer simply to an "outsider/nonmember's" perspective for reasons we outline below.

${ }^{4}$ We discussed, in the previous section, the various ways in which the analyst can warrant their treatment of an encounter as an intercultural one (in which emic-etic perspectives are salient) as opposed to simply an interpersonal one. In Chang and Haugh’s (2011) study, this warrant was grounded in evaluations of the apology elicited from Australian and Taiwanese informants.

${ }^{5}$ This example has been transcribed using standard CA transcription conventions (Jefferson, 2004).
} 
$15 \mathrm{~J}$ : oh, that's okay. yeah, yeah, yeah. I- I just

16 thought oh probably you are busy with something

17 so you ah probably were easy to- to (0.2)

18 for(hhh)get it .

[move 2: absolution]

$19 \mathrm{~W}$ : yeah we were pretty busy actually?

[move 3: response to absolution]

While the apology emerged as part of a longer interaction, for the sake of simplicity we focus here on only the apology sequence proper. In the excerpt above, there are three basic sequential moves: (1) the apology itself, (2) the response of the apology-recipient to the apology, and (3) the response of the apology-producer to the apology-recipient's response to the apology. The participants can thus be analysed as taking up distinct footings (Goffman, 1981) in that sequence, that is, their interactional alignments with respect to the social actions within that sequence (Haugh \& Chang, 2015), such as apology-producer, apology-recipient, and so on.

Given these distinct footings, each of these three sequential moves arguably has the potential to occasion two distinct evaluative perspectives ${ }^{6}$ :

a. Wayne's evaluation of his apology (emic)

[move 1]

b. Joyce's evaluation of Wayne's apology (etic)

c. Joyce's evaluation of her absolution (emic)

[move 2]

d. Wayne's evaluation of Joyce's absolution (etic)

e. Wayne's evaluation of his response to Joyce's absolution (emic)

[move 3]

f. Joyce's evaluation of Wayne's response to her absolution (etic)

If we take into account each participant's likely inferences about the other's evaluations of their conduct the situation becomes even more complex:

a'. Joyce's inference about Wayne's evaluation of his apology (etic)

[move 1]

b'. Wayne's inference about Joyce's evaluation of his apology (etic)

(and so on...)

What we see, then, is that there is an entwining of emic and etic perspectives on the talk and conduct of both self and other, which is here constitutive of the interaction as one that is intercultural. ${ }^{7}$ The point for the analyst, then, is not simply whose perspective we are dealing with (i.e. Wayne or Joyce), but whose perspective on whose talk or conduct (i.e. Wayne on Wayne, Wayne on Joyce, Joyce on Joyce, Joyce on Wayne), and also the moral grounds of the evaluation in question (i.e. emic or etic). For that reason it is of particular importance in analysing (im)politeness in intercultural encounters to distinguish between the footings of those participants themselves (e.g. apology-producer versus apology-recipient), and the emicetic perspectives they bring to bear on their evaluations of their respective social actions. It is

\footnotetext{
${ }^{6}$ We say potential because it is not necessarily the case that any interaction involving participants from different cultural backgrounds involves an interplay of emic-etic perspectives, but only those where it is demonstrably an intercultural - as opposed to simply an interpersonal - encounter.

${ }^{7}$ The inferences we make as analysts about the likely evaluations of each participant are licensed through examining both the design of the turn that implements the action in question as well as the subsequent response to that prior action (Haugh, 2015a; Mitchell \& Haugh, 2015).
} 
for that reason that the notions of perspective and "perspectivising” (ten Thije, 2006) are critical to analysing and theorising intercultural (im)politeness.

Stance taking and evaluating in intercultural communication are also strongly interconnected with issues of morality and immorality at the metapragmatic level. Observing others from an etic perspective entails framing the behaviour of others from one's own moral perspective , through the lenses of moral values, that is, one's own perception of how things 'should be'. ${ }^{8}$ However, while emic understandings of the moral order are immanent to social practice, they generally remain tacit for the very reason that the "familiar scenes of everyday affairs, the world of daily life known in common with others" that underpin it are, by right of being "perceivedly normal courses of action”, and so "taken for granted” (Garfinkel, 1967: 35). An important exception to this is the case of ritual (see Terkourafi and Kádár, in the present volume), which maintains the moral order in a way that is highly salient from an insider perspective. Tacit understandings of the moral order tend to be reflected by references to moral values, in particular in cases when such understandings are breached (Garfinkel, 1967) or challenged and people's moral values surface in the form of metapragmatic comments (Haugh \& Kádár, forthcoming; Kádár \& Haugh, 2013). ${ }^{9}$

Notably, in the case of intercultural or intergroup encounters such comments often involve what might be for the producer an evaluation rooted in his or her own emic perspective, but for the target or recipient it is one rooted in a fundamentally etic perspective. Consider the following excerpts from a YouTube discussion board on a short film dedicated to the question of whether Chinese tourists have behavioural problems or not. ${ }^{10}$ Not surprisingly, this discussion generated considerable intergroup debate, with many of these comments involving some form of moralising. While the majority of Westerner commenters claimed that Chinese tourists are indeed rude, a number of Chinese and Western commenters argued that this very evaluative attitude is itself immoral. For example, a Western commenter Julius Machinebacon noted that the way in which one perceives Chinese behaviour depends on how one "treats them".

(2)

Nothing to do with the country. It is a question of education (no, I don't necessarily mean school or university, but how the parents have nurtured their children). [...] Apart from the rising patriotism (without actually looking at the facts in history) I have found living with Chinese people quite pleasant. And this mostly depends on how I see and treat them: not looking down upon them. (Julius Machinebacon)

\footnotetext{
${ }^{8}$ It is pertinent to note that morality in Whutnow's (1989) sense is an abstract notion, in that interactants do not necessarily associate what they perceive as violations of moral order with popular understandings of morality rooted in philosophy (see Kádár \& Marquez-Reiter [2015] for further discussion).

9 Thus, while this sort of "surfacing" of moral values is not limited to instances of intercultural communication, the potential for an interplay of emic and etic perspectives in intercultural encounters does perhaps increase the possibility that there will be observable breaches of the moral order (from an emic perspective).

${ }^{10}$ The recordings and subsequent discussion board were accessed at https://www.youtube.com/watch?v=8LPPTCS1QXc.
} 
Making reference to "properly treating others" itself involves a moral appeal, and so this statement also implies that those who make negative and overgeneralising comments about the Chinese are themselves committing an immoral act. In a similar manner, Austin $\mathrm{Wu}$, a Chinese commenter, makes an appeal to morality in evaluating those evaluating Chinese tourists as rude as themselves rude.

(3) Why you gotta be so rude, don't you know we are human too, I'm from China :) (Austin Wu)

It is thus apparent that evaluations of the talk and conduct of others, in particular, those accomplished through metapragmatic comments, are themselves a form of social action (Haugh, 2013; Kádár \& Haugh, 2013). It is for this reason that evaluations of (im)politeness, especially in intercultural or intergroup encounters, can be challenged on moral grounds.

\subsection{Identities and identification}

It is now firmly established that the perceived, claimed or attributed identities of participants are central to evaluations of (im)politeness (Blitvich, 2013; Kádár \& Haugh, 2013; Locher, 2008; Spencer-Oatey, 2005). It is by indicating what I think of you (i.e. your person) through my talk or conduct that evaluations of that talk or conduct as "(im)polite" may arise (Haugh \& Hinze, 2003). There is, however, an additional layer involved in the case of encounters that are recognisably intercultural ones, as understandings of the cultural identities of participants may also enter into evaluations of (im)politeness in a number of ways:

1. interactants can construct culturally-situated identities vis-à-vis the choice of (im)polite language use that index such identities,

2. they can discuss such choices in the form of post-event metadiscourses,

3. and also they can make metapragmatic comments about (claimed or perceived) (im)politeness behavioural differences.

Similar to the notion of culture, however, the notion of identity has been theorised in a number of different ways (see Blitvich \& Sifianou, this volume, for a useful overview).

While early work treated cultural identities as something that could be straightforwardly ascribed by the analyst, recent work has moved away from treating identities as relatively stable constructs towards a more dynamic account of identification, that is, the processes by which multiple situated identities are projected, negotiated and contested in interaction by participants (Bucholtz, 1999; Benwell \& Stokoe, 2006). In the case of intercultural encounters, then, the question is not "what is a person's cultural identity”, but rather, "how do people construct/re-present their cultural identity” (Dervin, 2012: 186), and, in particular, what are the roles of stereotyping and "othering" (that is, "objectification of another person or group" in such a way that "puts aside and ignores the complexity and subjectivity of the individual” [Dervin, 2012: 187]). In intercultural encounters, interactants may use understandings of 'cultural identities' as a discursive resource (Thornborrow, 2002), that is, as a means to influence or even manipulate their interlocutor's stances. In arguments between intercultural couples (Goncalves, 2013), for instance, one party's impolite attitude may be construed as culturally normative, and the 
spouse thereby positioned as an "outsider" who does not have sufficient command of the language/culture to properly evaluate the given attitude.

In the case of intercultural encounters, two identification processes of particular importance are those of "association" and "disassociation" (Bucholtz, 1999). Association emphasises similarity, while disassociation emphasises difference. They often become most salient when a non-member, that is, someone positioned as a cultural 'outsider' relative to a particular relational network attempts to associate him or herself with members or 'insiders' of that network. The question of what counts as dissociation or association is thus unavoidably relative, as it depends on the nature of a given relational network, and how individuals position themselves, or are positioned, as members or non-members.

Consider the following excerpt from an encounter between DK (who is of Hungarian nationality but recently arrived to a permanent position at a university in the north of England) and SL (a local from Yorkshire).

(4)

DK: Well dun, as we Yorkshire people say!

SL: ((smiles and amiably hits DK's shoulder))

The focus of association here is a regional group (i.e. Yorkshire) within a nation, rather than the nation per se (i.e. Britain). This interaction took place between one of the authors Dániel Kádár and his acquintance SL in Yorkshire. Upon congratulating his acquaintance on an achievement, Kádár switched to a Yorkshire accent by pronouncing done as dun, and also markedly emphasising his association with a Yorkshire identity through metapragmatically positioning himself as a member - albeit temporarily in this locally, situated interaction through using an inclusive 'we' pronoun. The reaction of SL seems to us to indicate that SL, who is a native of Yorkshire, that DK's attempt at associating, that is, as identifying with SL's cultural group as a (new) co-member, albeit temporally, was received positively (although SL may as well have been humouring DK). What is important to note here in particular is that DK's attempt at associating, that is, as identifying with SL's cultural group as a new member is open to evaluation as "friendly" and thus "polite", on the one hand, but "overly presumptuous" and thus potentially "impolite” on the other. Identities, and processes of identification, are thus central to evaluations of (im)politeness in intercultural encounters. While in the excerpt above, DK's use of “in-group” language was received positively, the very same attempt may give rise to offence on other occasions, a point we shall explore in more detail in the first case study in section four.

\subsection{Accommodation and interculturality}

One further set of theoretical notions relevant to the analysis of (im)politeness in intercultural encounters was briefly alluded to in the previous section, namely, that of cultural accommodation and interculturality. Accommodation, or what Kim (2012) refers to as "adaptability" in the context of (ongoing) intercultural contact refers to the ways in which "individuals who, upon relocating to an unfamiliar cultural environment, strive to establish and maintain a relatively stable, reciprocal and functional relationship with the[ir] 
environment" (Kim, 2012: 233), both in the short-term (e.g. sojourners) and in the long-term (e.g. immigrants) (Kim, 2001). In example (4), which we discussed in the previous section, DK is not only at that moment explicitly adopting the local accent and claiming comembership, thereby demonstrating a willingness to adapt himself in order to establish relationships in the community, the two participants are co-constructing a hybrid intercultural or "third" space (Kramsch, 1993) where what DK is doing in identifying himself in this way at this moment in time is "open to translation, negotiation, resignification" (Kramsch \& Uryu, 2012: 218). That is to say, over time such moves by DK may be accepted, resisted or even challenged by those self-identifying (and identified by DK) as locals. The cultural identities of immigrants are invariably complex and continuously shaped in a dynamic intercultural space, and issues of (im)politeness and offence are one of the focal loci of processes of intercultural adaptation (Spencer-Oatey \& Franklin, 2009). It is worth noting, however, that such hybrid third spaces may also constitute a site of "difference and contestation” (Kramsch \& Uryu, 2012: 213) in intergroup or intercultural encounters, although this is a point that has yet to be explored in empirical studies of intercultural (im)politeness.

Yet even as one can talk of adaptation to perceived local norms there are also contradictory movements towards increased globalisation or internationalisation of what can be perceived as “(im)polite” (Sifianou, 2013). Indeed, the issue of what counts as "(im)polite” in a lingua franca encounter, that is, where none of the participants identifies or is identified as an L1 speaker of the language in question, poses considerable challenges for current theories of (im)politeness. As Kecskes (2013) has argued, what counts as "(im)polite” in English lingua franca (ELF) interactions is negotiated by those participants. The question such a position raises, however, is on what basis are such understandings negotiated? An evaluation of (im)politeness necessarily involves invoking some sort of moral grounds for that evaluation. In the case of ELF interactions, questions arise as to what those moral grounds are and how they are co-constituted? Are the participants' perceived understandings of (im)politeness grounded in what they might expect L1 speakers of particular varieties of English to do, or are they grounded in an hybrid space where a variety of (sometimes contradictory) norms are mixed or conflated? Drawing on a distinction between participants' understandings and the various emic-etic footings in which these understandings may be situated arguably offers some way forward to addressing the complex nature of (im)politeness in intercultural encounters.

\section{Approaches in intercultural (im)politeness research}

The study of (im)politeness in intercultural encounters has followed a trajectory that has been more or less the inverse of that of studies of (im)politeness in cross-cultural settings. While (im)politeness research as a field initially focused primarily on politeness, and only more recently in the past decade has moved to consider impoliteness (see Culpeper \& Hardaker, this volume), and even more recently the realm of “mixed messages", including mock impoliteness, mock politeness and so on (see Culpeper, Haugh and Sinkeviciute, this volume), the study of intercultural (im)politeness has witnessed the opposite trend. In the latter case, while most researchers initially focused on analysing instances of "unintended impoliteness" or "failed politeness", in recent years there has been a shift towards examining 
instances of "politeness" in intercultural encounters. This broadening of the focus of studies of intercultural (im)politeness reflects the more general shift in the field of intercultural communication away from conceptualising intercultural interaction as inevitably a site of misunderstanding or misapprehension (Sarangi, 1994; Bührig \& ten Thije, 2006). Making note of such paradigm shifts should not, however, be taken as implying that more recent studies are somehow superior to earlier ones. Our view is that whether one focuses on "unintended impoliteness", "politeness” or "genuine impoliteness” in intercultural encounters, or whether one's focus is intercultural encounters in which there are both first language and additional language speakers, or alternatively lingua franca settings, there remains significant unfinished business. Our aim in this section is to briefly outline some of the key studies of intercultural (im)politeness to date with the view to highlighting both what progress has been made in the field, and what significant gaps nevertheless remain.

Much of the effort of researchers has been directed towards the ways in which differences in speech practices and situation-specific expectations can give rise to (unintended) offence or interactional troubles (Haugh, 2010: 143-150). Such cases have generally been analysed as forms of "unintended impoliteness" or "failed politeness” (e.g. Bailey, 1997; Clyne, 1994; Grainger, 2011; Günthner 2000; Holmes, Marra \& Schnurr, 2008; Lee-Wong, 2002; Miller, 1995; Nakane, 2006; Ting-Toomey, 2009; Tyler, 2009). Divergences in the speech practices and expectations of participants in intercultural encounters is traditionally assumed to be a function of pragmatic transfer, that is, where lexical items, syntactic structures or pragmatic routines that are preferred in one language are used (or not used) in another.

Yet as Inagaki (2011) notes, issues of understanding in intercultural encounters are sometimes much more complex than might be illuminated through a singular focus on pragmatic failure. What may also be involved is the participants own history of experiences and concomitant values and presumptions that underlie both how they interpret and how they evaluate the talk and conduct of others and themselves. In other words, what gives rise to offence in the intercultural encounter in question may not be divergences in the practices of those participants per se, but instead a deeper form of misunderstanding (Haugh, 2008: 219224), in which what is involved is not a "wrong” understanding or "lack of understanding" (malentendu or méconnaissance), but rather an inability to understand the other's perspective (mésentente) (Rancière, 1999). A number of studies have focused on the ways in which participants take offence at the conduct of cultural others, and yet remain unaware of the deeper misunderstandings that underpin these perceptions of impoliteness (e.g. Chang \& Haugh, 2011; Haugh, 2008; Spencer-Oatey, 2002; Spencer-Oatey \& Xing, 2000; Wang \& Spencer-Oatey, 2015).

More recently, a number of studies have focused on the ways in which participants in intercultural encounters may also accomplish perceptions of each other as "polite" and "friendly" (e.g. Bubel, 2006; House, 2008, 2010; Miller, 1995, 2000; Ryoo, 2005). House (2008, 2010), for instance, has argued that what might be evaluated as “impolite” by first language speakers of English is not treated as such by speakers of English as an additional language in situations where English is being used as a lingua franca. These studies indicate that in examining (im)politeness in intercultural encounters it is important to remember that 
what is evaluated as (im)polite is ultimately locally negotiated by those participants, rather than simply being a function of putative or presumed cultural norms.

In examining the literature on intercultural (im)politeness it is striking to note that most of the studies to date have focused on institutional encounters (see also Holmes \& Schnurr, this volume), that is, (im)politeness in the workplace or in service encounters, rather than on everyday intercultural interactions amongst acquaintances, friends or family. Moreover, most studies have focused on intercultural (im)politeness in interactions where English is the primary language. Unlike cross-cultural (im)politeness research, where a wide range of languages (and language varieties) have been studied, the focus in intercultural (im)politeness research has been primarily on English. This reflects, in part, the extent to which English dominates intercultural encounters worldwide, yet it is not by any means the only language in the world through which intercultural encounters may be negotiated. A third notable gap is that the focus of intercultural (im)politeness research has primarily been on face-to-face encounters. There has been little research that has focused on intercultural (im)politeness in digitally-mediated forms of communication (see Graham \& Hardaker, this volume), with the exception of studies of intercultural (im)politeness in email (e.g. Bjørge, 2007; Stroińska \& Cecchetto, 2013). This is perhaps surprising given the extent to which the Internet affords intergroup encounters to a degree and scope that were simply unimaginable even a few decades ago. Part of the problem for the researchers is, of course, establishing the extent to which digitally-mediated interactions can be analysed as interpersonal, intergroup or intercultural in nature, as in many such interactions the background of participants is not readily accessible (either to the other participants or the researcher). Yet intergroup conflicts mediated through various forms of digital communication are clearly on the rise (Kádár, Haugh \& Chang, 2013; Lorenzo-Dus, Blitvich \& Bou-Franch, 2011; Perelmutter, 2013). It thus appears to be an area ripe for further analysis and theorisation that will enrich our understanding of intercultural (im)politeness more generally.

\section{Case studies}

\subsection{Taking offence in intergroup encounters}

As we have pointed out, much of the focus in intercultural (im)politeness research has been on the ways in which what or how something is said or done may give rise to (unintended) offence or perceptions of impoliteness in intercultural encounters. It has been increasingly acknowledged, however, that what is of paramount importance in intercultural interactions is not the cultural identities that might be ascribed to the participants by the researcher, but rather the cultural identities the participants themselves co-construct. A key focus of attention should thus arguably be not simply on what or how something was said or done, but on who said or did it, and the ways in which evaluations of (im)politeness can arise through participants construing the interaction, at least at that point in time, as an intergroup one.

To illustrate what we mean by this claim, we focus on a conversation from the UK version of Big Brother that generated considerable controversy when it was broadcast in June 2007. The interaction in question involved three housemates, Emily Parr, Charley Uchea and Nicky Maxwell. We focus here first on what occasioned the controversy leading to Emily 
being removed from the house, namely, Emily calling Charley a "nigger” after Charley has been relating her worries about being pregnant. ${ }^{11}$

(5a) Big Brother Season 8, 6 June 2007

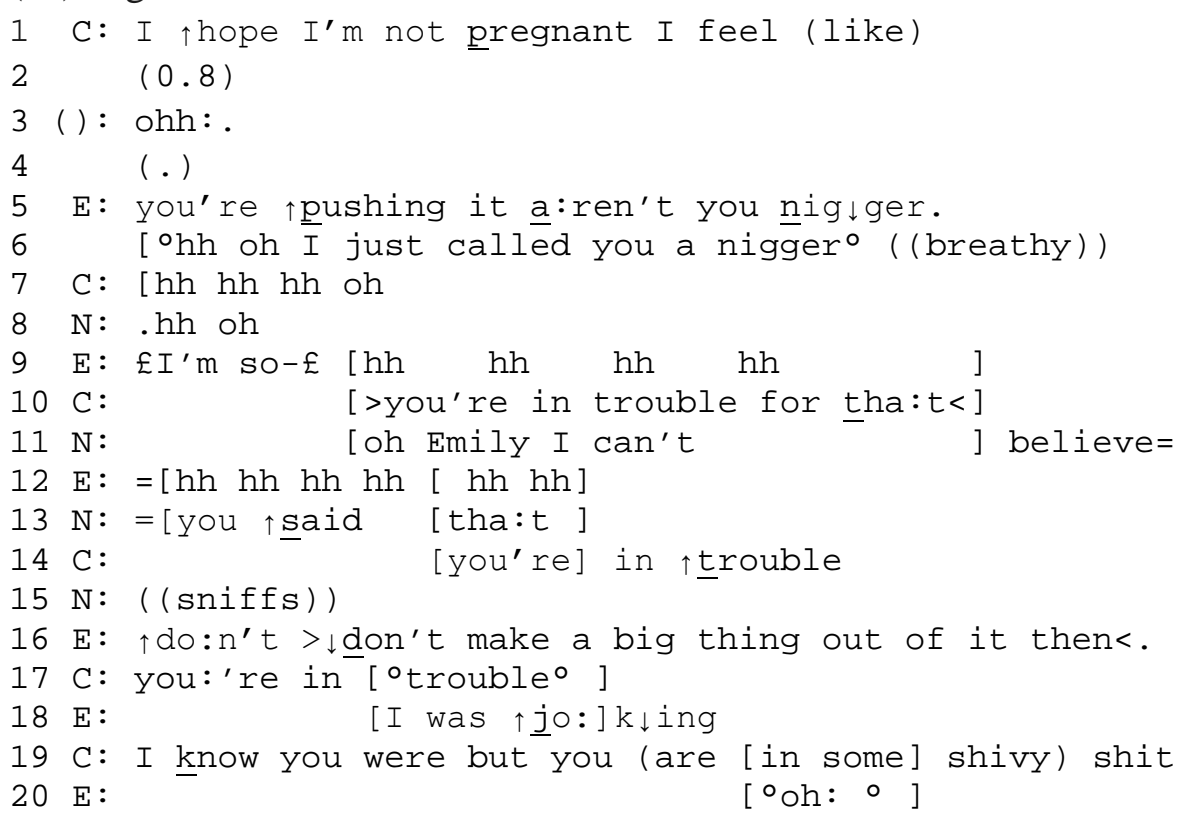

What becomes immediately apparent in the subsequent turns is that this is treated by all three participants as a moral transgression. The transgression in question is not simply the use of a racial slur (Croom, 2011), but that it has been directed by a white participant (Emily) towards a black participant (Charley). However, the transgression is construed in different ways by the three participants. Emily immediately construes it as a "slip" (line 6), and then launches what is possibly an aborted apology that dissolves into laughter (line 9), and then claims to have been "joking” (line 18). The latter represents an attempt to divert moral culpability for using the slur in question as a slur (Allan, 2015) by claiming non-serious intent (Haugh, 2016b). While Charley acknowledges this latter claim to non-serious intent (line 19), she repeatedly asserts that Emily is "in trouble" for saying it (lines 10, 14, 17, 19). Nicky also expresses disbelief (lines 11,13), thereby construing it as a serious transgression given it defies what is expectable (and thus appropriate) conduct.

Charley subsequently makes it clear that in her view the problem is not with the use of the term per se, but its use by Emily, as can be observed in the following excerpt.

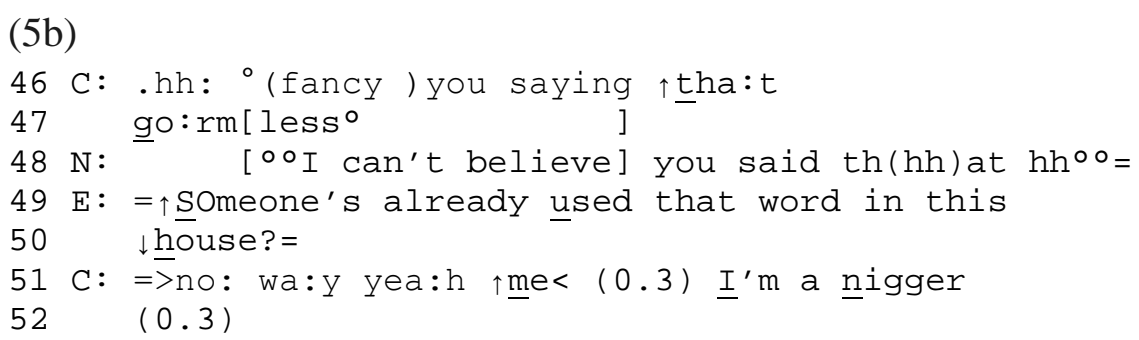

\footnotetext{
${ }^{11}$ A recording of the incident in question was accessed at: https://www.youtube.com/watch?v=07qZqXDbPS8. They have been transcribed using standard CA transcription conventions (Jefferson, 2004).
} 
$53 \mathrm{~N}: \operatorname{pf}[\mathrm{f}$ hh hh]

$54 \mathrm{C}$ : $[\mathrm{I}$ am $]$ one (.) .hh (.) $\uparrow$ fancy you:

55 saying $\downarrow$ it $>$

In claiming the slur is something that she is able to use in reference to herself (line 51), but not something she expects Emily would say (lines 46, 54-55), Charley is not only ascribing the slur a property of sayability (i.e. it is something that can be used by some person but not others), she is construing the exchange itself as an intergroup one. That is, Emily is cast here as a cultural "other", a non-member of the group in which using the slur is acceptable, a categorisation which had not been oriented to as relevant by those participants up until that point in their conversation.

There is, of course, another layer to this particular episode in that the participants orient to the fact that their conversation is being broadcast and thus likely "overhead" by a (ratified) viewing audience (Dynel, 2011; Haugh, 2013). When Charley explicitly claims Emily is "in trouble" this constitutes an allusion to that participation framework, as the persons with whom she is "in trouble" are, of course, the viewing audience and the producers of the show. In other words, the use of the slur by Emily will be offensive to them.

Notably, Charley herself treats the taking of offence herself as a sensitive social action (Haugh, 2015b). In the following excerpt, Charley first explicitly construes Emily's use of the term as indexing a "racist" attitude (lines 83-84).

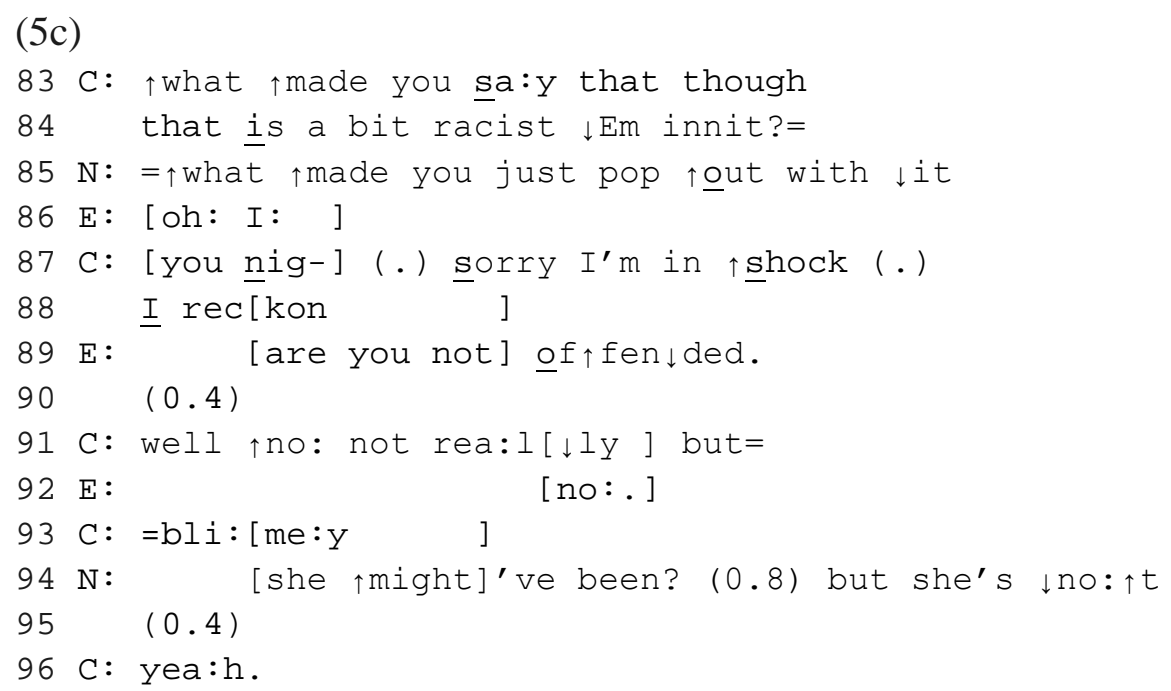

Nicky goes on to construe this as inviting an account from Emily as to why she used the term (lines 85). However, rather than completing any such account (line 86), Emily asks whether Charley is "offended" (line 89), thereby implicitly acknowledging that Charley may well be. Notably, Charley's denial is non-straightforward (line 91), and ends with an expression of surprise (line 93), while Nicky offers that Charley could legitimately have felt offended but didn't in this case (line 94). In that way, they jointly resist Emily's construal of her possible feelings of offence as something that is straightforwardly deniable (cf. line 92). Overall, then, the participants orient to the taking of offence as a sensitive social action. This may well be partly because straightforwardly doing so might undermine the relational connection 
(Arundale, 2006) they have established in the house thus far. There are also possible selfpresentation issues at play here, especially given Charley is aware that her response is likely being - or to be - observed by the viewing audience.

While in this brief analysis we have focused on a somewhat complex case in which construing an interaction as an intergroup encounter proffers, in part at least, the grounds for taking offence, the opposite may, of course, hold true. That is to say, participants may construe some talk or conduct that is open to evaluation as "impolite" as not actually "impolite" because it involves an "unintended slip" by a cultural other, following what Firth (1996) refers to as the "let it pass" principle. On that basis, is also possible that in some instances construing oneself as the cultural "other" licenses talk or conduct that would otherwise attract social sanction. Our point, then, is that construing an interaction as an intercultural or intergroup one may itself licence evaluations of (im)politeness.

\subsection{Metalexemes in intercultural contact}

Given the focus on intercultural encounters in English and "politeness" or "impoliteness" in most studies to date, we have elected to focus here in our second case study on examining the ways in which metalexemes that represent phenomena with (im)polite implications - such as 'booing', 'jousting' or 'heckling' - are translated into other languages. ${ }^{12}$ The term 'metalexeme' refers to words that are used about (im)politeness-related phenomena, and as such can be distinguished from other words and expressions. An examination of such metalexemes has not only revealed that many of the English technical terms that are used in the realm of (im)politeness research have very different pragmatic implications in other languages, ${ }^{13}$ but also that many of such metalexical 'synonyms' across languages come into existence through intercultural contact and subsequent appropriation. This case study is somewhat different from the previous one, in that it represents intercultural contact at a macro-level: essentially, it shows the ways in which a certain (im)politeness-related phenomenon is appropriated in a new cultural context. We believe that this is an important dimension of intercultural (im)politeness, which should be discussed in order to demonstrate that: (a) intercultural research is useful in order to understand differences between the culture-specific meanings of seemingly 'technical' metalexemes such as 'heckling', and (b) to illustrate that an intercultural perspective is useful for capturing particular elements of macro-level cultural contact.

In order to illustrate this point, let us focus on 'heckling'. Heckling describes a situation in which an unratified person decides to interrupt a public talk, and as such it is a pragmatic phenomenon with clear potential for evaluation as "impolite". In Chinese, there is no appropriate equivalent for the metalexeme 'heckling': it is referred to by two metalexemes zhiwen 质问 (interrogate) and qihong 起哄 (make loud noises), which are used in a seemingly interchangeable way when it comes to heckling incidents. Examples (6) and (7) illustrate this point:

\footnotetext{
12 This case study forms part of a larger project presented in Kádár (2016) and Kádár and Ran (2015).

${ }^{13}$ See also Haugh (2016a) for discussion of the challenges of the use of English as a scientific metalanguage in “(im)politeness” research.
} 
(6)

奥巴马演讲韩籍学生激烈质问

Oubama yanjiang zao Han-ji xuesheng jilie zhiwen

Obama's talk was violently heckled by a Korean national student

(Retrieved from: http://news.qq.com/a/20131126/011972.htm)

(7)

奥巴马演讲遭起哄

Oubama yanjiang zao qihong

Obama's talk has been heckled

(Retrieved from: http://v.youku.com/v_show/id_XMzA4MjkyNDI4.html)

Yet, while seemingly referring to the same thing, it is well established that (meta)lexical 'synonyms' are unlikely to have exactly the same meaning, as context, style and other factors influence why a given lexeme is chosen (Schreyer, 1976). Kádár (2016) has thus examined the relationship between zhiwen/qihong and the act of heckling, as well as the way in which these metalexemes are used to frame foreign heckling incidents.

Historical research, which we only describe briefly here, has shown that variants of zhiwen and qihong were not used in the sense of 'heckling' before the $19^{\text {th }}$ and $20^{\text {th }}$ centuries (Kádár, forthcoming). More precisely, the Chinese used qihong to describe the interruption of public performances of art and entertainment, that is, they had a 'native' lexeme for heckling, with a relatively limited interpretation compared to the meaning of the English metalexeme. This has changed as the Chinese adopted the British parliamentary system in the 1910s: suddenly parliamentary debates emerged, and they adopted 'heckling' in the sense used in the UK at that time: asking challenging questions from a ratified position. Thus, in the 1910s the Chinese directly borrowed an English term, to coin heckling metalexemes for two different contexts: zhiwen for politics, and qihong for arts. This gradually changed in the 1940s to 1950s when zhiwen appeared first in the sense of interruption, and subsequently in the 1950s to 1960s when zhiwen and qihong are both used to describe heckling in politics. At the same time qihong remains the only lexeme for sports and arts heckling.

The historical background of zhiwen and qihong points towards a key difference between their modern meanings as forms of heckling: data shows that zhiwen refers to serious, rightful and potentially 'moral' acts of heckling, primarily in the context of politics, whilst qihong refers to 'non-serious' and/or 'immoral' heckling acts in both politics and other areas such as sports and arts. Thus, in Chinese, due to the moral implications associated with heckling, the choice of zhiwen vs. qihong involves taking an explicit attitudinal stance with respect to the perceived 'morality' of the 'heckling' in question (Bednarek, 2008; Haddington, 2012). This means that a foreign heckling incident, for example, cannot be 'reported' without the translator taking an explicitly positive or negative attitudinal stance towards it. This also implies that in academic and popular discourse we are potentially talking about different phenomena when we discuss 'heckling' in English and Chinese. This challenges the common assumption that academic studies of (im)politeness phenomena use 
technical terms that capture the same phenomena across different language and cultures (Haugh, 2016a; Kádár and Paternoster 2015). This does not mean that we cannot or should not use technical terms in the field, but that we should be aware of the fact that these technical terms may have very different implications across languages and cultures. In other words, if we use English as an academic language, it is important to attempt to broaden the meanings of technical terms (aka metalexemes), in order for them to include various culturespecific implications (Kádár 2016).

In order to illustrate this point, let us provide two examples which represent the way in which foreign heckling events are reported in Chinese media, which reveal that zhiwen and qihong convey the authors' stances on the event being reported:

奥巴马发表讲话遭打断 男子气势汹汹对其质问 当地时间 2014 年 7 月 24 日， 美国洛杉矶，奥巴马在洛杉矶贸易技术学院中就经济问题表讲话。一些民众拉 横幅或手持标牌抗议奥巴马遣返非法移民 $[\cdots]$ 其间，一名男子气势汹汹的打断 奥巴马的讲话对其提出质问，随后该名男子被安保人员带离现场。

'Obama's speech is being interrupted: A young man truculently heckles him 24.07.2014, Los Angeles: Obama held a presentation on economics at the Los Angeles School of Business and Economics. A few persons held up a banner that expressed opposition against Obama's [plan of] deporting of illegal immigrants [...] A young man truculently interrupted Obama's speech and heckled him, and following this he was removed by the security personnel.' (Retrieved from Zhongguo ribao 中 国日报 China Daily)

(9)

\section{奥巴马演讲耶鲁学生起哄 总统发飙怒指干扰者}

Obama's speech is heckled by a student from Yale University - The president angrily points his finger at the intruder

(Retrieved from Zhongqing wanbao 重庆晚报 Chongqing Evening News)

A comparison of examples (8) and (9) reveals that zhiwen in the first and qihong in the second represent different attitudinal stances. The author of example (8) appears to be on the side of the protesters: they use the idiomatic expression qishi-xiongxiong (气势汹汹) truculently in reference to the young heckler's behaviour; this idiom has positive overtones in Chinese as it has connotations of the protester's braveness. Also, the author does not use any honorific title for Obama and, on the nonlinguistic level the article shows a photo of the protesters. Example (9), on the other hand, describes the heckler as an 'intruder' (ganraozhe 干扰者), refers to Obama with the honorific 'President' zongtong (总统); on the nonlinguistic level it shows an appealing photo of Obama who points to the heckler with a determined face. Note that while the word 'angrily' may imply for Western readers that Obama lost his temper, in the Chinese context, when it comes to discussion about politicians, 
the expression of anger tends to appear as morally justifiable action, i.e. it adds to the positive image of Obama in this particular context. To sum up, this section has illustrated that foreign heckling incidents cannot be 'objectively' repeated in Chinese (although one wonders whether there is such a thing as objective translation), simply because in Chinese the two major heckling metalexemes imply attitudinal stances. This imposes restraints on the appropriation of foreign heckling notions in Chinese metadiscourses. Even more importantly, this case study has demonstrated that issues of interculturality and hybridity permeate even the very metalexicon that we use in (im)politeness research.

\section{Summary}

In this chapter we have suggested that despite ongoing critiques of the notion of culture, to ignore encounters which participants themselves construe as intercultural would amount to throwing out the baby with the bathwater. Indeed, ongoing debates about how to define culture indicate, we would suggest, that it is a highly productive analytical construct, albeit one that is difficult to pin down (see also Sifianou and Bltivich, this volume). In undertaking studies of intercultural (im)politeness, then, what is needed is a considered analytical approach that draws not only from a particular theoretical stance on culture itself, but also an appreciation of the importance of grounding one's analysis in the understandings of the participants themselves. The latter requires, in turn, a firm grasp of the relevance of the emicetic distinction, processes of identification, and accommodation to studies of intercultural (im)politeness. We have also suggested that intercultural encounters can be studied at both a local, situated level, as well as at a broader, macro level.

Looking forward, we would argue that intercultural (im)politeness research has much to offer the field of (im)politeness more generally. In our view, morally-imbued evaluations lie at the heart of (im)politeness (Haugh, 2015a; Haugh \& Kádár, forthcoming; Kádár \& Haugh, 2013). However, moral systems do not develop within individuals but across fields, that is, a dynamic relational network, which is not only imbued with historicity, but also with ongoing interactions and emerging relationships (Kádár \& Haugh, 2013: 78). Yet while this means that evaluations of (im)politeness are almost inevitably conservative in the moment, they are nevertheless also always open to change over time within relational fields. Intercultural encounters constitute a potent enabler of social change as they represent an arena where the moral underpinnings of (im)politeness may be readily challenged or contested by participants, thereby accelerating changes in moral systems. Given rapid changes in the range of persons with whom we may interact afforded by developments in digital communications and an increasingly globalised world economy, it seems fair to say that the $21^{\text {st }}$ century is rapidly becoming a century of intercultural and intergroup communication. It thus follows that we can no longer afford for the study of (im)politeness in intercultural and intergroup encounters to remain a mere side avenue or digression for (im)politeness researchers. While this will invariably lead to more complex theories of (im)politeness, such intricacy must arguably be embraced as an inevitable part of explaining social life in a rapidly changing world. 


\section{References}

Allan, Keith (2015). When is a slur not a slur? The use of nigger in 'Pulp Fiction'. Language Sciences, 52(1), 187-199.

Arundale, Robert A. (2006). Face as relational and interactional: a communication framework for research on face, facework, and politeness. Journal of Politeness Research, 2(2), 193-216.

Bailey, Benjamin (1997). Communication of respect in interethnic service encounters. Language in Society, 26, 327-356.

Bednarek, Monika (2008). Emotion Talk across Corpora. Basingstoke: Palgrave Macmillan.

Benwell, Bethan, \& Stokoe, Elizabeth (2006). Discourse and Identity. Edinburgh: Edinburgh University Press.

Bjørge, Anne Kari (2007). Power distance in English lingua franca email communication. International Journal of Applied Linguistics, 17(1), 60-80.

Blitvich, Pilar Garcés-Conejos (2013). Introduction: Face, identity and politeness. Looking backward, moving forward: from Goffman to practice theory. Journal of Politeness Research 9, 1: 1-33.

Bubel, Claudia (2006). "How are you?” "I'm hot” An interactive analysis of small talk sequences in British-German telephone sales. In Kristin Bührig \& Jan D. ten Thije (Eds.), Beyond Misunderstanding (pp. 245-259). Amsterdam: John Benjamins.

Bucholtz, Mary (1999). “Why be normal?”: Language and identity practices in a community of nerd girls. Language in Society, 28(2), 203-223.

Bührig, Kristin, \& ten Thije, Jan D. (Eds.) (2006). Beyond Misunderstanding. Amsterdam: John Benjamins.

Busch, Dominic (2009). The notion of culture in linguistic research. Forum: Qualitative Social Research (Forum Qualitative Sozialforschung) 10(1): Article 50.

Carbaugh, Donal (2005). Cultures in Conversation. London: Routledge.

Carbaugh, Donal (2012). A communication theory of culture. In Anastacia Kurylo (ed.), Inter/Cultural Communication. Representation and Construction of Culture (pp.6987). Thousand Oaks, CA: Sage.

Chang, Wei-Lin Melody, \& Haugh, Michael (2011). Evaluations of im/politeness of an intercultural apology. Intercultural Pragmatics, 8(3), 411-442.

Clifford, James (1988). The Predicament of Culture: Twentieth-Century Ethnography, Literature, and Art. Harvard, MA: University of Harvard Press.

Clyne, Michael (1994). Inter-cultural Communication at Work. Cambridge: Cambridge University Press.

Corbett, John (2003). An Intercultural Approach to English Language Teaching. Clevedon: Multilingual Matters.

Culpeper, Jonathan (2011). Impoliteness: Using Language to Cause Offence. Cambridge: Cambridge University Press.

Croom, A. M. (2011). Slurs. Language Sciences, 33(3), 343-358.

Dervin, Fred (2012). Cultural identity, representation and othering. In Janet Jackson (Ed.), The Routledge Handbook of Language and Intercultural Communication (pp.181194). London: Routledge. 
Dynel, Marta (2011). Revisiting Goffman's postulates on participant statuses in verbal interaction. Language and Linguistics Compass 5/7: 454-465.

Eelen, Gino (2001). A Critique of Politeness Theories. Manchester: St Jerome.

Firth, Alan (1996). The discursive accomplishment of normality: on 'lingua franca' English and conversation analysis. Journal of Pragmatics, 26, 237-259.

Garfinkel, Harold (1967). Studies in Ethnomethodology. Englewood Cliffs, NJ: Prentice-Hall. Goffman, Erving (1981). Forms of Talk. Philadelphia: University of Pennsylvania Press.

Goncalves, Kelly (2013). Conversations of Intercultural Couples. Berlin: Mouton de Gruyter.

Grainger, Karen (2011). Indirectness in Zimbabwean English: A study of intercultural communication in the UK. In Francesca Bargiela-Chiappini \& Dániel Z. Kádár (Eds.), Politeness across Cultures (pp. 171-193). Basingstoke: Palgrave Macmillan.

Grainger, Karen, \& Mills, Sara (2015). Directness and Indirectness across Cultures. Houndsmill, Basingstoke: Palgrave Macmillan.

Gudykunst, William B. (2005). Cross-Cultural and Intercultural Communication. New York: Sage.

Gumperz, John. (1982). Discourse Strategies. Cambridge: Cambridge University Press.

Günthner, Susanne (2000). Argumentation and resulting problems in the negotiation of rapport in a German-Chinese conversation. In Helen Spencer-Oatey (Ed.), Culturally Speaking. Managing Rapport through Talk across Cultures (pp. 217-239). London: Continuuum.

Haddington, Pentti (2012). Pragmatics of stance. The Encyclopedia of Applied Linguistics. London: Blackwell.

Halualani, Rona Tamiko, Mendoza, Lilly S., \& Drezwiecka, Jolanta A. (2009). Critical junctures in intercultural communication studies: a review. The Review of Communication, 9(1), 17-35.

Harris, Marvin (1976). History and significance of the emic/etic distinction. Annual Review of Anthropology 5: 329-350.

Haugh, Michael (2008). Intention and diverging interpretings of implicature in the “uncovered meat” sermon. Intercultural Pragmatics, 5(2), 201-229.

Haugh, Michael (2010). Intercultural im/politeness and the micro-macro issue. In Anna Trosborg (Ed.), Pragmatics across Languages and Cultures (pp. 139-166). Berlin: Mouton de Gruyter.

Haugh, Michael (2013). Im/politeness, social practice and the participation order. Journal of Pragmatics, 58, 52-72.

Haugh, Michael (2015a). Im/politeness Implicatures. Berlin: Mouton de Gruyter.

Haugh, Michael (2015b). Impoliteness and taking offence in initial interactions. Journal of Pragmatics, 86, 36-42.

Haugh, Michael (2016a). The role of English as a scientific metalanguage for research in pragmatics: Reflections on the metapragmatics of "politeness” in Japanese. East Asian Pragmatics, 1(1), 39-71.

Haugh, Michael (2016b). “Just kidding”: Teasing and claims to non-serious intent. Journal of Pragmatics, 95, 120-136. 
Haugh, Michael, \& Chang, Wei-Lin Melody (2015). Troubles talk, (dis)affiliation and the participation order in Taiwanese-Chinese online discussion boards. In Marta Dynel \& Jan Chovanec (Eds.), Participation in Public and Social Media Interactions (pp.99133). Amsterdam: John Benjamins.

Haugh, Michael, \& Hinze, Carl (2003). A metalinguistic approach to deconstructing the concepts of 'face' and 'politeness' in Chinese, English and Japanese. Journal of Pragmatics, 35(10-11), 1581-1611.

Haugh, Michael and Dániel Z. Kádár (forthcoming). The Metapragmatics of (Im)Politeness. Cambridge: Cambridge University Press.

Hofstede, Geert (1991). Cultures and Organizations: Software of the Mind ( $2^{\text {nd }}$ edn). London: McGraw-Hill.

Holliday, Adrian (1999). Small cultures. Applied Linguistics, 20(2), 237-264.

Holmes, Janet, Marra, Meredith, \& Schnurr, Stephanie (2008). Impoliteness and ethnicity: Maaori and Paakehaa discourse in New Zealand workplaces. Journal of Politeness Research, 4(2), 193-219.

Holmes, Janet, Marra, Meredith, \& Vine, Bernadette (2012). Politeness and impoliteness in ethnic varieties of New Zealand English. Journal of Pragmatics, 44(9), 1063-1076.

House, Juliane (2008). (Im)politeness in English as lingua franca discourse. In Miriam Locher \& Jürg Strässler (Eds.), Standards and Norms in the English Language (pp. 351-366). Berlin: Mouton de Gruyter.

House, Juliane (2010). Impoliteness in Germany: Intercultural encounters in everyday and institutional talk. Intercultural Pragmatics, 7(4), 561-595.

Imahori, Todd, \& Cupach, William (2005). Identity management theory. Facework in intercultural relationships. In William Gudykunst (Ed.), Theorizing about Intercultural Communication (pp. 195-210). Thousand Oaks, CA: Sage.

Inagaki, Noriko (2011). Unpacking the hearer's interpretation of situated politeness. In Bethan Davies, Michael Haugh, \& Andrew John Merrison (Eds.), Situated Politeness (pp. 147-164). London: Continuum.

Jackson, Janet (Ed.). (2012). The Routledge Handbook of Language and Intercultural Communication. London: Routledge.

Jefferson, Gail. (2004). Glossary of transcript symbols with an introduction. In Gene Lerner (Ed.), Conversation Analysis: Studies from the First Generation (pp. 13-23). Amsterdam: John Benjamins.

Kádár, Dániel Z. (2013). Relational Rituals and Communication: Ritual Interaction in Groups. Basingstoke: Palgrave Macmillan.

Kádár, Dániel Z. (forthcoming). Historical intercultural sociopragmatics: A study on ritualisation. Accepted for publication in Journal of Historical Pragmatics.

Kádár, Dániel Z. (2016). Politeness, Impoliteness, and Ritual: Maintaining the Moral Order in Interpersonal Interaction. Cambridge: Cambridge University Press.

Kádár, Dániel Z., \& Haugh, Michael (2013). Understanding Politeness. Cambridge: Cambridge University Press. 
Kádár, Dániel Z., Haugh, Michael, \& Chang, Wei-Lin Melody (2013). Aggression and perceived national face threats in Mainland Chinese and Taiwanese CMC discussion boards. Multilingua, 32(3), 343-372.

Kádár, Dániel Z., \& Paternoster, Annick (2015). Historicity in metapragmatics: A study on 'discernment' in Italian metadiscourse. Pragmatics, 25(3): 369-391.

Kádár, Dániel Z., \& Ran, Yongping (2015). Ritual in intercultural contact: A metapragmatic case study of heckling. Journal of Pragmatics 77: 41-55.

Kádár, Dániel Z., and Rosina Marquez-Reiter (2015). (Im)politeness and (im)morality: Insights from intervention. Journal of Politeness Research 11(2): 239-260.

Kecskes, Istvan (2013). Intercultural Pragmatics. Oxford: Oxford University Press.

Kidwell, Mardi (2000). Common ground in cross-cultural communication: Sequential and institutional contexts in front desk service encounters. Issues in Applied Linguistics, 11(1), 17-37.

Kim, Young Yun (2012). Beyond cultural categories. Communication, adaptation and transformation. In Janet Jackson (Ed.), The Routledge Handbook of Language and Intercultural Communication (pp.229-243). London: Routledge.

Kramsch, Claire (1993). Context and Culture in Language Teaching. Oxford: Oxford University Press.

Kramsch, Claire, \& Uryu, Michiko (2012). Intercultural contact, hybridity, and third space. In Janet Jackson (Ed.), The Routledge Handbook of Language and Intercultural Communication (pp.211-225). London: Routledge.

Lee-Wong, Song Mei (2002). Contextualizing intercultural communication and sociopragmatic choices. Multilingua, 21(1), 79-99.

Locher, Miriam A. (2008). Relational work, politeness and identity construction. In Gerd Antos \& Eija Ventola (Eds.), Handbooks of Interpersonal Communication (pp. 509540). Berlin: Mouton.

Locher, Miriam A., Bolander, Brook, \& Höhn, Nicole (2015). Introducing relational work in Facebook and discussion boards. Pragmatics 25(1): 1-21.

Lorenzo-Dus, N., Blitvich, Pilar Garces-Conejos, \& Bou-Franch, Patricia (2011). On-line polylogues and impoliteness: the case of postings sent in response to the Obama Reggaeton YouTube video. Journal of Pragmatics, 43(10), 2578-2593.

Marra, Meredith (2015). Language and culture in sociolinguistics. In Farzad Sharifian (ed.), The Routledge Handbook of Language and Culture (pp.373-385). London: Routledge.

Martin, Judith, \& Nakayama, Thomas K. (1999). Thinking dialectically about culture and communication. Communication Theory, 9(1), 1-25.

Martin, Judith, Nakayama, Thomas K., Carbaugh, Donal (2012). The history and development of the study of intercultural communication and applied linguistics. In Janet Jackson (ed.), The Routledge Handbook of Language and Intercultural Communication (pp.17-36). London: Routledge.

McSweeney, Brendan (2002). Hofstede's model of national cultural differences and their consequences: A triumph of faith - a failure of analysis. Human Relations, 55(1), 89118 , 
Mead, George (1934). Mind, Self and Society. Chicago, IL: University of Chicago Press. Miller, Laura (1995). Two aspects of Japanese and American co-worker interaction: giving instructions and creating rapport. Journal of Applied Behavioral Science, 31(2), 141161.

Mills, Sara (2003). Gender and Politeness. Cambridge: Cambridge University Press.

Mills, Sara (2011). Communities of practice and politeness. In Bethan Davies, Michael Haugh, \& Andrew John Merrison (Eds.), Situated Politeness (pp. 73-87). London: Continuum.

Mitchell, Nathaniel, \& Haugh, Michael (2015). Agency, accountability and evaluations of impoliteness. Journal of Politeness Research, 11(2), 207-238.

Nakane, Ikuko (2006). Silence and politeness in intercultural communication in university seminars. Journal of Pragmatics 38(11): 1811-1835.

Paulston, Christina Bratt, Kiesling, Scott F., \& Rangel, Elisabeth S. (Eds.). (2012). The Handbook of Intercultural Discourse and Communication. Malden, MA: WileyBlackwell.

Perelmutter, Renee (2013). Klassika zhanra: The flamewar as a genre in the Russian blogosphere. Journal of Pragmatics, 45(1), 74-89.

Pike, Kenneth (1967). Language in Relation to a Unified Theory of the Structure of Human Behavior (2nd. ed.). The Hague: Mouton.

Ramírez-Cruz, Héctor (forthcoming). ¡No manches güey! Service encounters in a Hispanic American intercultural setting. Journal of Pragmatics.

Rancière, Jacques (1999). Disagreement. Minneapolis: University of Minnesota Press.

Ryoo, Hye-Kyung (2005). Achieving friendly interactions: a study of service encounters between Korean shopkeepers and African-American customers. Discourse and Society, 16(1), 79-105.

Sarangi, Sarangi (1994). Intercultural or not? Beyond celebration of cultural differences in miscommunication analysis. Pragmatics, 4(3), 409-427.

Schreyner, Rüdiger. (1976). Synonyms in context. Working Papers in Language and Linguistics 7:8-21.

Scollon, Ron, \& Scollon, Suzanne Wong (1995). Intercultural Communication: A Discourse Approach. Malden, MA: Blackwell.

Scollon, Ron, Scollon, Suzanne Wong, \& Jones, Rodney (2012). Intercultural Communication: A Discourse Approach (3rd ed.). Malden, MA: Wiley-Blackwell.

Sharifian, Farzad (2011). Cultural Conceptualisations and Language. Amsterdam: John Benjamins.

Sifianou, Maria (2013). The impact of globalisation on politeness and impoliteness. Journal of Pragmatics 55: 86-102.

Stroińska, Magda, \& Cecchetto, Vikki (2013). Facework in intercultural e-mail communication in the academic environment. In Farzad Sharifian \& Maryam Jamarani (Eds.), Language and Intercultural Communication in the New Era (pp. 160-180). London: Routledge.

Spencer-Oatey, Helen (Ed.) (2000). Culturally Speaking: Managing Rapport through Talk Across Cultures. London: Continuum. 
Spencer-Oatey, H. (2002). Managing rapport in talk: using rapport sensitive incidents to explore the motivational concerns underlying the management of relations. Journal of Pragmatics, 34(5), 529-545.

Spencer-Oatey, Helen (2005). (Im)Politeness, face and perceptions of rapport: unpackaging their bases and interrelationships. Journal of Politeness Research, 1(1), 95-120.

Spencer-Oatey, Helen, \& Franklin, Peter (2009). Intercultural Interaction: A Multidisciplinary Approach to Intercultural Communication. Basingstoke: Palgrav Macmillan.

Spencer-Oatey, Helen, \& Xing, Jianyu (2003). Managing rapport in intercultural business interactions: A comparison of two Chinese-British welcome meetings. Journal of Intercultural Studies 4(1): 33-46.

ten Thije, Jan D. (2006). Notions of perspective and perspectivising in intercultural communication research. In Kristin Bührig \& Jan D. ten Thije (Eds.), Beyond Misunderstanding (pp. 97-151). Amsterdam: John Benjamins.

Thornborrow, Joanna (2002). Power Talk: Language and Interaction in Institutional Discourse. London: Longman.

Ting-Toomey, Stella (2009). Facework collision in intercultural communication. In Francesca Bargiela-Chiappini \& Michael Haugh (Eds.), Face, Communication and Social Interaction (pp. 227-249). London: Equinox.

Ting-Toomey, Stella, \& Kurogi, Atsuko (1998). Face work competence in intercultural conflict: an updated face-negotiation theory. International Journal of Intercultural Relations, 22(2), 187-225.

Tyler, Andrea (1995). The coconstruction of cross-cultural miscommunication. Studies in Second Language Acquisition, 17(2), 129-152.

van der Bom, Isabelle, \& Mills, Sara (2015). A discursive approach to the analysis of politeness data. Journal of Politeness Research, 11(2), 179-206.

Wang, Jiayi, \& Spencer-Oatey, Helen (2015). The challenge of building professional relations across cultures: Chinese officials in America. In Elizabeth Christopher (Ed.), International Management and Intercultural Communication: A Collection of Case Studies. Volume 1 (pp. 90-107). Basingstoke: Palgrave Macmillan.

Watts, Richard (2003). Politeness. Cambridge: Cambridge University Press.

Whutnow, Robert (1989). Meaning and Moral Order: Explorations in Cultural Analysis. Berkeley: University of California Press.

Wolf, Hans-Georg (2015). Language and culture in intercultural communication. In Farzad Sharifian (Ed.), The Routledge Handbook of Language and Culture (pp.445-459). London: Routledge.

Wortham, Stanton, \& Locher, Michael (1999). Embedded metapragmatics and lying politicians. Language \& Communication 19(2): 109-125.

Žegarac, Vladimir, Spencer-Oatey, Helen, \& Ushioda, Ema (2014). Conceptualising mindfulness-mindlessness in intercultural interaction. International Journal of Language and Culture, 1(1), 75-97. 